\title{
Empowerment of Women through Entrepreneurship Development in Emerging Economies: A Case of India
}

\author{
Siby Abraham ${ }^{1}$ Himachalam Dasaraju² Jency Treesa ${ }^{3}$ \\ sibyabraham@shcollege.ac.in
}

\begin{abstract}
The present paper purports to overview women empowerment through women entrepreneurship development in emerging economies. Women empowerment through entrepreneurship has assumed greater importance to push forward the economic development of developing countries across the world. The development of a sound entrepreneurship culture is an index of the empowerment of people, industrial development, and the overall economic prosperity of any country. Women entrepreneurship has become a very important driver of women empowerment and sustainable economic progress. The paper reviews women empowerment, female entrepreneurship, gender equity, institutional support and problems of women in rural areas. It also suggests practical solutions to surmount the problems confronted by the women. The physical, material and technical supports have to be extended to the women entrepreneurs to get success and empower themselves. An imperative need is to promote and encourage women to take part and exhibit their mite in the central stream of economic activities and thereby promote economic growth and sustainable development. It provides further insights on the relationship between women empowerment and entrepreneurship and needs to focus special attention on promoting women empowerment as a part of UN sustainable development goals.
\end{abstract}

Keywords: Women empowerment, Women entrepreneurship, Gender equity, Inclusive growth, Sustainable development goals.

\section{Introduction}

\subsection{Background}

The concept of women empowerment and entrepreneurship development have assumed greater relevance in developed as well as developing nations across the world. The development of entrepreneurship, which is a human activity, has become imperative in the economic development and prosperity of any country. The success of an economy

1. Siby Abraham, PhD is an assistant Professor, Department of Economics, Sacred Heart College (Autonomous), Kochi, Kerala, India.

2. Prof. Himachalam Dasaraju is a Senior Fellow \& Professor Emeritus (former), Commonwealth Visiting Fellow, UK. He has served at Sri Venkateswara University, Tirupati, Andra Pradesh, India.

3. Jency Treesa, PhD is an Assistant Professor, Department of Commerce, St. Teresa's College (Autonomous), Kochi, Kerala, India. 
undisputedly depends on its entrepreneurial quality, skills, competence, and performance of the industrial sector. For the developing countries, it is an urgent need to find, nourish and develop competent women entrepreneurship for strengthening women empowerment. Economic empowerment is a sine qua non for elevating women's status in every developing economy. Women in emerging economies in general and India, in particular, are deprived of many socio-economic benefits and status in society. They are relegated in multiple ways in the society though they constitute a considerable proportion of the total population.

According to the World Bank, empowerment means "the process of increasing the capacity of individuals or groups to make choices and to transform those choices into desired actions and outcomes". The core of this process is actions which build both individual and collective assets and improve the efficiency and fairness of the organizational and institutional context which govern the use of these assets (UN, 2012). The empowerment is multidimensional encompassing the extension of freedom of choice and action in social, economic, and political spheres thereby upholding one's life with adequate control over resources and decisions. Women's freedom is often restricted due to the inherent gender inequality prevailing in homes and society. For the empowerment, women require a lot of assets and capabilities at the individual level to transform the untapped assets into products or services. The right approach towards achieving this end could be through entrepreneurship development among women. The entrepreneurial spirit with good education is one of the most important means of empowering women with the knowledge, skills, and self-confidence necessary to participate fully in the development process of any economy (UNFPA Report, 1995).

\subsection{Objectives of the study}

The specific objectives of the study are:

(a) To examine the problem of gender gap and the empowerment of women through entrepreneurship.

(b) To discuss the policy measures undertaken by the Government of India to promote women entrepreneurship.

(c) To study the constraints and barriers to women entrepreneurship in India and suggest measures to tackle the problems of women entrepreneurs.

\section{Research Methodology}

The study aims firstly, to examine the problem of gender gap existing in India and the policy measures taken by the Government of India to promote women entrepreneurship. Content analysis was used for analyzing the textual material required for this. In this approach building a coding frame is central (Schreier, 2012). Extensive literature review was done to gather published data and the based on the research objectives data was coded based on the theme of women entrepreneurship and policy measures taken to promote women entrepreneurship. To know the problem of women entrepreneurs, one to one expert interview was conducted among 6 women entrepreneurs. Meuser and Nagel (2009) discuss the expert interviews as a 
specific form of applying semi- structured interviews. The problems of women entrepreneurs enlisted in the latter part of the paper is the experts' subjective orientations, points of view and interpretations.

\section{Review of Literature}

There is a growing body of literature that recognizes women empowerment as a solution for bridging the gender equality. The literature review is based on themes as Women empowerment and gender equity, Women's Empowerment: Global Scenario, Women Empowerment: Indian Scenario, Women Entrepreneurship as a Means of Women Empowerment, Women's Entrepreneurship - present need, scope of women entrepreneur, and Institutional Support for Women Entrepreneurship in India.

Women entrepreneurship is defined as self-employment or the creation of a business where the total or majority of the ownership and the decision-making processes are owned and managed by women respectively (Carter \& Shaw, 2006).

\subsection{Women empowerment and gender equity}

Women's empowerment is a critical aspect of achieving gender equality. Gender equality is a human right, but the entire world faces a persistent gap in access to resources and opportunities and decision-making power for women and men. Gender equality is a fundamental human right, and it's a necessary foundation for a healthy, peaceful, prosperous, and sustainable world. Women are deprived of opportunities than men in fulfilling basic needs, higher education, health, safety, economic participation and political representation. Protecting the rights of women and giving them equal opportunities promises gender equality and also ensures the attainment of international development goals. Empowered women increase the quality of health and productivity of their families, communities, and countries, creating a ripple effect that benefits everyone. Women's empowerment and gender equality ensure progress in all areas and was one of the eight-millennium goals envisioned by the world leaders at the Millennium Summit held in New York in 2000.

The Gender-related Development Index (GDI) and the Gender Empowerment Measure (GEM) were introduced in 1995 in the Human Development Report of the UNDP with the prime aim of the measures were to add a gender-sensitive dimension to the Human Development Index (HDI). It is high time to presume that every woman should be selfreliant, self-sufficient, healthy, resilient, respected, courageous, strong, equal treatment, and heard. For strengthening this movement every year on the 8th of March observed globally the International Women's Day to review the progress and propose the action plan to achieve the target. International Women's Day was organized globally on March 8, 2021, and debated on the main theme "Choose to Challenge". Further, the celebrations focused on the review of the achievements of women and calls for action to empower women to create a genderequal world. 
Empowerment of women and minimizing the gender gaps in the world of work will in general help to achieve the 2030 Agenda for Sustainable Development and particularly achieve the Sustainable Development Goals: Goal 1 on ending poverty, Goal 2 on food security, Goal 3 on ensuring health, Goal 5 to achieve gender equality, Goal 8 to promote full and productive employment and decent work for all; and also Goal 10 on reducing inequalities (UN-SDGs, 2020).

\subsection{Women's empowerment: Global scenario}

Prior studies have confirmed the theory of "push" and "pull" factors when it comes to the motivations of business leaders (Orhan \& Scott, 2001; Sarri \& Trihopoulou, 2005). Several lines of evidence suggest that women in developing countries are generally "pushed" toward entrepreneurship through factors such as economic hardship and state initiatives, whereas women in developed countries are more likely to be "pulled" into entrepreneurial activity through the pursuit of achievement, autonomy, and self-fulfillment (Malach-Pines et al., 2010).A report of the United Nations says that "Women constitute half of the world population, perform nearly two-thirds of work hours, receive one-tenth of the world's income and own less than one-hundredth per cent of the world's property." Women are still suffering from discrimination, exploitation, and victimization across the world; hence, the need of the hour is the empowerment of women in all categories - social, political, and economic. Keeping pace with all these tasks to empower the women through education, gender budgeting, and all those rights which are necessary for women to sustain their life in a suitable and appropriate environment, women entrepreneurship is another way to empower them. In the process of industrialization and globalization, mass education, and a sense of right of equality in economic activity, women are putting their steps in the entrepreneurial world. They have to perform multifaceted roles in society along with their professional life.

A recent study in the United States indicated that 1 out of every 11 adult women is an entrepreneur. Women business owners generated overall employment of 18 million workers and earned from $\$ 2$ to $\$ 3$ trillion in U.S. economy revenues. Women substantially contribute towards economic development and their contribution in the development process has been continually increasing all over the world. The steep rise in the number of female entrepreneurs can be attributed to many reasons like passion to pursue their ideas, the desire to become self-employed, and the urge to address philanthropic causes and this is at par with the rationale of their male counterparts. It is a truth that the women in almost all the known societies of the world have not enjoyed the same status, privileges, rights, and powers as men (Mayoux, L, 2000).

According to Human Development in South Asia Report (2000), Women's Empowerment is a change in the context of a woman's life, which enables her to increase her capacity for leading a successful human life. Women's empowerment is one of the essential factors that promote human development. The Programme of Action of the International Conference on Population and Development envisages that the empowering and ensuring autonomy of women thereby improving their political, social, economic, and health status are highly 
relevant and important for sustainable human development (UNFPA, 2007). The concept of human development has evolved out as a broader measure of the socio-economic progress of the nation. Human development is measured in the form of a composite index called the Human Development Index (HDI). In 1995, the Human Development Report put forward the concept of Gender-related Development Index (GDI) and Gender Empowerment Measure (GEM). GDI, while measuring the achievements in the same dimensions and variables as the HDI, also incorporates inequality in achievement between women and men (Anand et. al, 1995).

Women's Empowerment is a buzzword worldwide, as the global decisions of various countries as a part of global partnership for development, centering on population development, more so on women empowerment. The task of promoting women's empowerment is included in the Millennium Development Goals and International Conference on Population and Development (ICPD) Programme of Action (Principle-4). The ICPD Programme of Action referred to the Cairo Consensus which was remarkable in its recognition that reproductive health and rights, as well as women's empowerment and gender equality, are cornerstones of population and development programs worldwide. The United Nations Fund for Population Activities (UNFPA) partners with governments, other agencies and civil society to advance UNFPA's mission. Two frameworks guide its efforts, viz., the Programme of Action adopted at the 1994 International Conference on Population and Development and the Millennium Development Goals which target to reduce extreme poverty by the end of 2015 (www.unfpa. org).

The world population increased from 3.6 billion to 7 billion between 1970 and 2011 . As that population becomes more educated, its growth rate will slow down. The Human Development Report of 1995 focused on gender inequality in the development process of various countries. It highlighted the fact that among 900 million illiterates in the developing world, women outnumbered men. Among the 1.3 billion people in poverty, 70 per cent were women. But the invisible non- monitored contribution of women to the world output was a staggering \$ 11 trillion per annum i.e., nearly 50 per cent of the official estimated world output of $\$ 22$ trillion. The report also said that women's position was unenviable in all countries and in all respects. Even in administrative and managerial careers, women were far behind. In India in 1992, women accounted for 2.3 per cent of employed in the carder and the rest were occupied by men.

The Gender-related Development Index (GDI) and the Gender Empowerment Measure (GEM) were introduced in 1995 in the Human Development Report of the UNDP to add these measurements of gender-sensitive dimensions to the Human Development Index (HDI). 
Figure 1: Global Gender Gap Index

\section{GLOBAL GENDER GAP INDEX 2021}

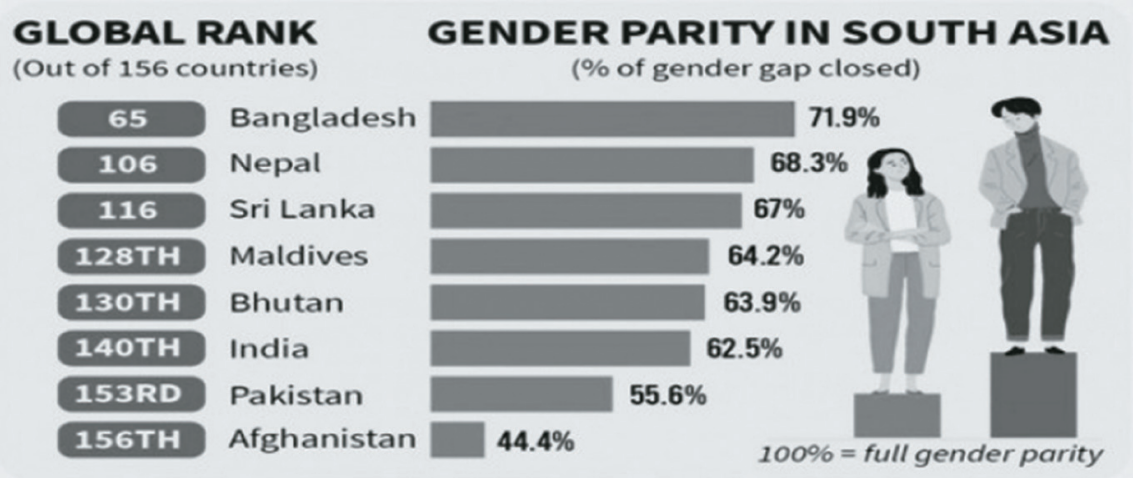

Source: World Economic Forum (WEF)-Global Gender Gap Index, 2021.

It is observed from the above diagram of the Global Gender Gap Index 2021 of WEF, that India ranked 140 globally out of 156 countries, and 62.5 per cent of the gender gap in the gender parity in South Asia. India is ranked as 140 (slipped 28 places) among 156 countries, as per the Global Gender Gap Report 2021, by World Economic Forum. In 2020, India was at 112 th position among 153 countries. Iceland remains the topper as the most gender-equal country in the world for the twelfth time.

Figure 2: South Asia's Global / Regional-wise Gender Gap Index, 2021

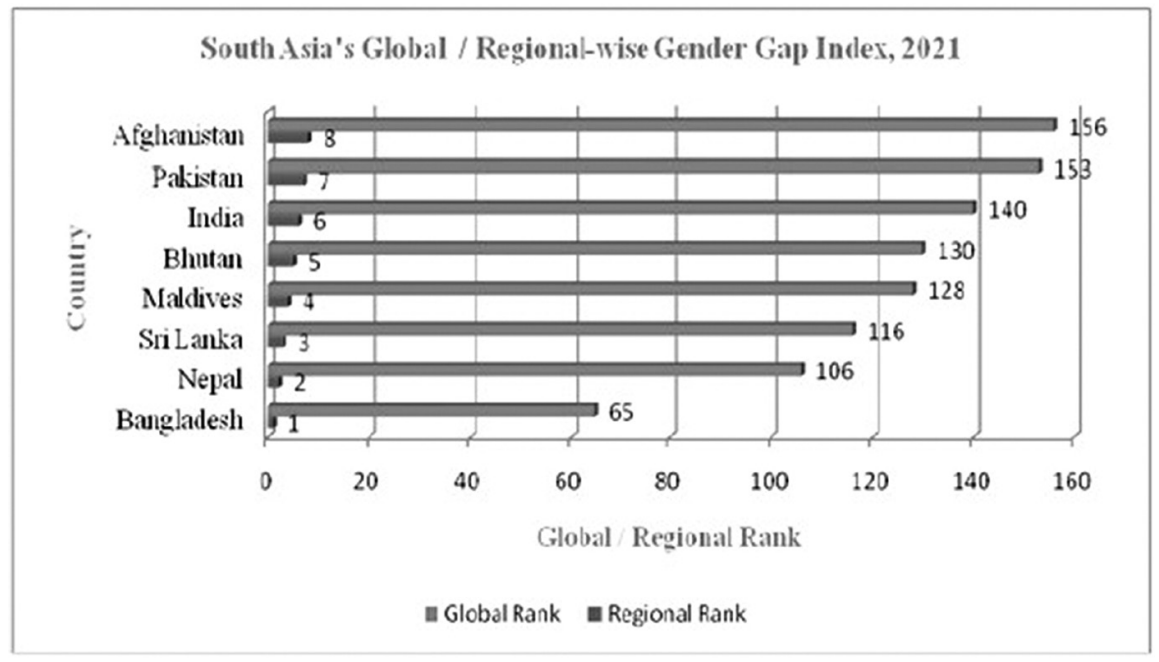

Source: World Economic Forum (WEF)- Global Gender Gap Index 2021. 
Table:1 The Global Gender Gap Index rankings in South Asia, 2021

\begin{tabular}{|l|c|c|c|}
\hline Country & \multicolumn{2}{|c|}{ Rank } & Score \\
\hline & Regional & Global & \\
\hline Bangladesh & 1 & 65 & 0.719 \\
\hline Nepal & 2 & 106 & 0.683 \\
\hline Sri Lanka & 3 & 116 & 0.670 \\
\hline Maldives & 4 & 128 & 0.642 \\
\hline Bhutan & 5 & 130 & 0.639 \\
\hline India & 6 & 140 & 0.625 \\
\hline Pakistan & 7 & 153 & 0.556 \\
\hline Afghanistan & 8 & 156 & 0.444 \\
\hline
\end{tabular}

Source: Global Gender Gap Report, 2021

According to the report of the South Asia's Global/Regional-wise Gender Gap Index, 2021, India got 6th regional rank and 140th global rank as mentioned earlier, as detailed in Table no.1.

Figure 3 : Country-wise Human Development Index Rank, 2019

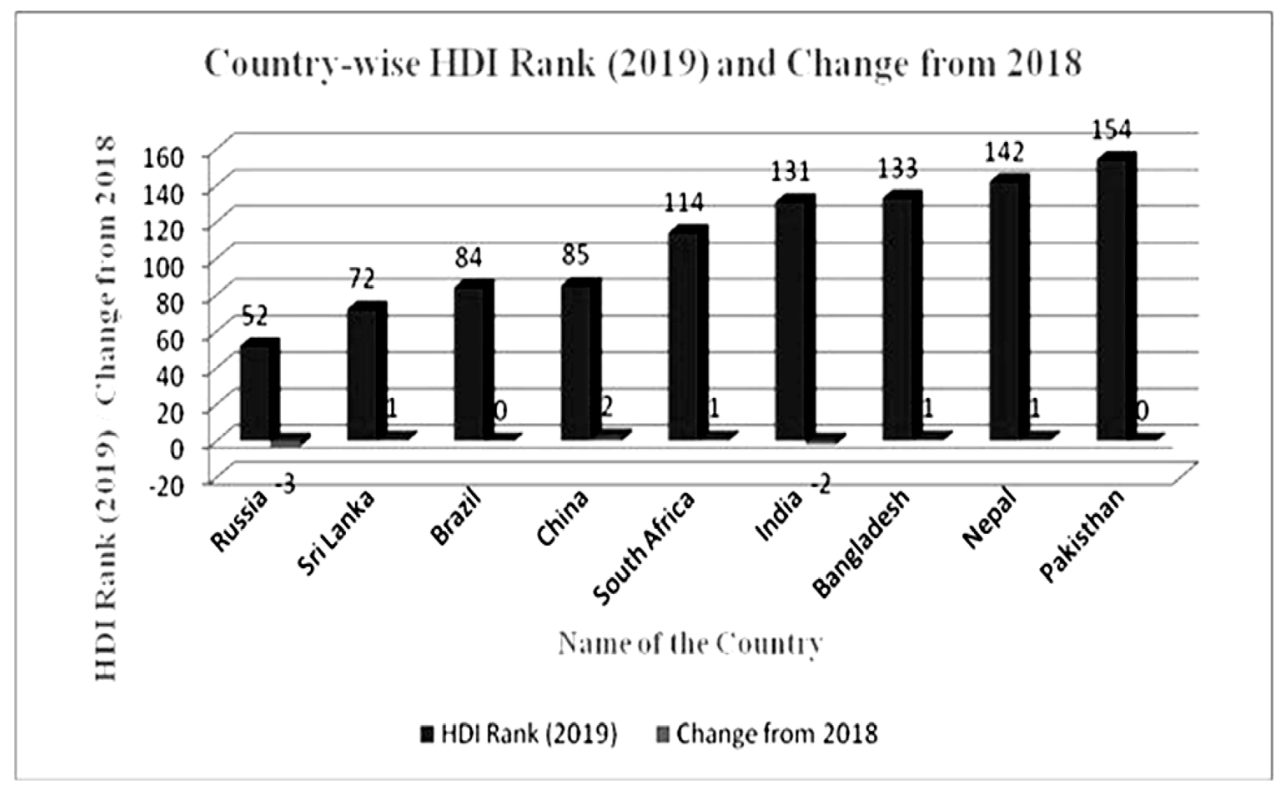


Table 2: Country-wise Human Development Index Rank, 2019

\begin{tabular}{|l|c|c|}
\hline Country & HDI Rank (2019) & Change from 2018 \\
\hline Russia & 52 & -3 \\
\hline Sri Lanka & 72 & 0 \\
\hline Brazil & 84 & 2 \\
\hline China & 85 & 1 \\
\hline South Africa & 114 & -2 \\
\hline India & 131 & 1 \\
\hline Bangladesh & 133 & 1 \\
\hline Nepal & 142 & 0 \\
\hline Pakisthan & 154 & 1 \\
\hline
\end{tabular}

Source: World Economic Forum (WEF)- Global Gender Gap Index 2021.

Interestingly, India dropped a place in the overall Human Development Index (HDI) ranking though improved in its absolute value of HDI to 0.645 in 2019 from 0.642 in 2018, a change of -2 from 2018. We have miles to go to reach the considerable global HDI, followed by Bangladesh and Nepal. India dropped a place in the overall Human Development Global Gender Gap Report which is annually published by the World Economic Forum (WEF). It benchmarks countries on their progress towards gender parity in four dimensions: Economic participation and opportunity, educational attainment, health and survival, and political empowerment (WEF, 2021).

Table 3 : India's profile in world gender gap: Score comparison in 2006 and 2021

\begin{tabular}{|l|c|c|c|c|}
\hline \multirow{2}{*}{ Index / Factors } & \multicolumn{2}{|c|}{2006} & \multicolumn{2}{c|}{2021} \\
\cline { 2 - 5 } & Score & Rank & Score & Rank \\
\hline Global Gender Gap Index & 0.601 & 98 & 0.625 & 140 \\
\hline Economic participation and opportunity & 0.397 & 110 & 0.326 & 151 \\
\hline Educational attainment & 0.819 & 102 & 0.962 & 114 \\
\hline Health and survival & 0.962 & 103 & 0.937 & 155 \\
\hline Political empowerment & 0.227 & 20 & 0.276 & 51 \\
\hline
\end{tabular}

Source: World Economic Forum (WEF)- Global Gender Gap Index 2021.

Table no. 3 presents the score comparison of India's profile in world gender gap in 2006 and 2021. It can be observed from the table that the global gender gap index score rose from 0.601 in 2006 to 0.625 in 2021 and the rank rose from 98 in 2006 to 140 in 2021. It indicates that the global rank slipped 42 ranks from 2006 to 2021. Likewise, all other factors like economic participation and opportunity, educational attainment, health and survival, and political empowerment also declined from 2006 to 2021. 
Gender equality apart from being a fundamental right is a necessity for a peaceful and sustainable world. When compared to the past decades we see positive changes with regard to gender equality. The enrolment of girls in the schools increased, fewer girls are forced into early marriages and more women take up leadership roles. Covid-19 is said to have reversed the limited progress that has been made on gender equality and women's rights. Disproportionate role is assigned to women in responding to the virus, including as frontline healthcare workers and caretakers at home. The unpaid job of women at home increased many folds during lock down times, especially due to the school closures and the increased need of care for elderly people.

\subsection{Women empowerment: Indian scenario}

Economic empowerment is a sine qua non for enhancing the status of women in the society in any developing economy like India as Indian women are deprived of many socio-economic benefits and status in the society. They are backward in many ways in the society though they constitute considerably in the total population. As per the 2001 census, women constituted about 48 per cent of the total population of the country. In India, women head only 10 per cent of the total household, and the ownership of land and other assets are mainly in the name of the men of the family. Moreover, women in the economically active age group 15-59 years constitute 58.4 per cent of the total women population. For empowering women, this needs to be targeted because if a woman is economically empowered it becomes much easier for her to become socially empowered. These women need to take part actively in education/ training, employment, income generation, and developmental process. The situation is so worst in the case of women in backward areas. Keeping in view the plight of Indian women particularly, the government of India has been taking a lot of measures to improve the living standards and social status of the women. Accordingly, a plethora of programs for uplifting the status of women in society is taken up over some time.

The government of India has given importance to the development of women since the Planning era. But only in the Sixth Five Year Plan the focus of the government changed from women welfare to the development of women. The Eighth Plan set vigil to ensure that benefits of development from different sectors do not negatively affect women. The Rashtriya Mahila Kosh was set up in 1993 to meet the credit needs of poor women. The Ninth Plan was remarkable as it envisaged "empowerment of women" and "Convergence of existing services" available in both women-specific and women-related sectors. The Tenth Plan (2002-07) planned at "empowering women as the agent of socio-economic change and development". In tune with the recommendation of the National Policy for Empowerment of Women, the Tenth Plan put forward a three-fold strategy for empowering women, through social empowerment, economic empowerment, and gender justice.

The socio-cultural pattern of the Indian society is largely based on the Hindu Caste system in which class, caste, ethnicity, and gender largely determine the socio-economic status of various populations. Moreover, Indian society is a patriarchal society with masculinity as one of the characteristics in most of the families of the society which influence all aspects of the social, cultural, and economic life of the people (Oliver D'Souza, 2011). 
Women's Economic Empowerment (WEE) has important linkages with gender equality. For attaining gender equality, India has formulated several schemes and legislations that aim to empower women and enhance their participation in the economy. Unfortunately, these initiatives have had only limited success. According to the WEF 2021 report, India has slipped on the political empowerment index as well by 13.5 percentage points, and a decline in the number of women ministers, from 23.1 per cent in 2019 to 9.1 per cent in 2021.But it still scored relatively well compared to other countries, ranking at 51 in women's participation in politics. In the index of education attainment, India has been ranked at 114 . The WEF's Global Gender Gap Report 2021, indicates the following in the Indian context (WEF, 2021).

1. India ranked 140 among 150 countries in the overall global rankings. It is noticed that India has fallen 28 places in the overall ranking globally.

2. In South Asia, India lagging behind the neighboring countries like Bangladesh, Nepal, Bhutan, Sri Lanka, and Myanmar.

3. India's position in the political empowerment index decreased by 13.5 percentage points.

4. India has ranked 114th in the index of education attainment.

5. India has fared badly in Health and Survival, which includes sex ratio and economic participation in national and regional economic activity.

6. In India, the estimated earned income of women is only one-fifth of men's, which puts the country among the bottom 10 globally on this indicator.

In India the proportion of women in senior and managerial positions remains very low; only 14.6 percent of these positions are held by women and there are only 8.9 percent of firms with female top-level managers. Further, the estimated earned income of women in India is only one-fifth of that of men, which puts the country among the bottom ten globally on this indicator, it said. Discrimination against women is also reflected in the health and survival sub-index statistics. With 93.7 percent of this gap closed to date, India ranks among the bottom five countries in this sub-index. Wide gaps in sex ratio at birth are due to the high incidence of gender-based sex-selective practices. In addition, more than one in four women has faced intimate violence in her lifetime, as explained in the report. "Conversely, 96.2\% of the educational attainment sub-index gender gap has been closed, with parity achieved in primary, secondary and tertiary education. Yet, gender gaps persist in terms of literacy: onethird of women are illiterate (34.2\%) compared to $17.6 \%$ of men," the report added (Global Gender Gap Index 2021).

The extent of gender inequality is evident from the high incidence of violence against women, including violence at homes. Studies reveal that over one-third of adult women in India have experienced sexual or physical violence. Domestic violence is one of the most common forms of cruelty faced by women. These high levels of tolerance for domestic violence reveals the need for increased efforts to raise awareness of women's rights and the law among both women and men and community leaders (ADB, 2013). 


\subsection{Women entrepreneurship as a means of women empowerment}

Entrepreneurship always depends on the entrepreneurial talent and efficiency and it is a notable development indicator from a socio-economic point of view. It has emerged as a new major force for economic change and women, along with men have to be encouraged to take part so that women empowerment and economic development can be attained together. Entrepreneurship requires the ability to take the risk and coordinate the factors of production efficiently in an uncertain environment. Generally, women can work hard with a lot of commitment and dedication and their entrepreneurial qualities make a considerable influence on the success and failure of organizations. This has been widely recognized by the planners and they often emphasize moulding talented women as entrepreneurs who can transform the destiny of our nation with their business involvement.

The Government of India has defined women entrepreneurship as an enterprise owned and operated by women with a minimum of 51 per cent financial interest and women employees. Women entrepreneurs can perform the same tasks and responsibilities as their male counterparts. They need to explore the prospects of starting a new enterprise; undertake risks, introduce innovations, coordinate administration, control business, and provide effective leadership in all aspects of the business (Frankel, FR, 1997). Women should be encouraged to free themselves from the shackles of conservative traditional customs, which confine them mostly to household activities. Because of their capacity for hard work, commitment, and sense of responsibility they should be properly motivated and their talents and abilities have to be nurtured. In the small-scale industrial sector, there is considerable scope for their gainful employment and they can improve their standard of living, their own as well as that of people in general. But as the situation now prevails, there is no perceptible improvement in women entrepreneurship. It is most unfortunate because, in India's population, women are on par with men. But their participation in economic activity and share of income in the total resources of the country are pitiably very low.

In India, the ownership and management of business and industry has long been considered a male prerogative. It is important to note that as per the Planning Commission estimates, the total requirement of employment during 1990-95 would be about 65 million and during the decade 1995-2005, it would be 105 million, of which the major employment seekers would be from rural areas. Therefore, it is necessary to develop small-scale industrial units in areas where there is chronic unemployment, dearth of capital, lack of appropriate technical know-how, and certain inherent structural imbalances in the economy. Because this sector has a high potential for the generation of employment, the scope for dispersal of industrial units, narrowing down regional imbalances, utilization of hitherto untapped locally available resources, and for the promotion of entrepreneurship among women. Towards this end, the Government of India has taken several measures in the area of finance and managerial assistance for the promotion of women's enterprises. Despite these measures, the small-scale units are still plagued by a series of problems. The crux of the problem is that women entrepreneurs are found lacking in initiative, motivation, innovation, and the spirit of encountering risks which are closely associated with all business operations 
whether of women or men. Male domination encouraged by the long-established tradition of patriarchy practice has almost conditioned most of the women to a life of obedience, submissiveness, silent suffering, self-denial, and scarify as if these are great and inviolable virtues in themselves that all women should emulate. As a consonance, women's direct, active and dynamic participation in the economy and their contribution to its development have been grossly reduced and confined.

\subsection{Women's entrepreneurship - A present need}

Father of the Nation Mahatma Gandhi asserted rightly: "My greatest hope is women. They want a helping hand to help them out of the well in which they had been kept. They made record contribution during Satyagraha of 1931-32, they are waiting to be organized". He also said: "woman is the companion of the man gifted with equal mental capacities. She has the right to participate in all walks of life along with men. She has the same right to freedom and liberty as a man. She is entitled to a supreme place in her sphere of activity as man is. By sheer course of vicious customs, even the most ignorant and worthless men have been enjoying superiority over women for whom they do not deserve and ought not to have". In India and other developing countries, the ownership and management of businesses and industry have long been male prerogatives. This situation, fortunately, is changing gradually and in recent years women have begun to be aware of their potentials and their rights to participate in various economic activities including the fields of industry, service sector, and business. Educated women in cities are making their way into non-conventional fields such as consultancy, marketing, advertising, export of garments, interior decoration, handicrafts, dyeing and printing, food processing, Biotechnology, IT, etc. There is hardly a field in which they are not making their mark today.

The emergence of women entrepreneurs in India has increased over the years and it has significantly grown after the economic reforms in the 1990s. According to the Bain \& Company report on women entrepreneurship, India has 13.5-15.7 million women-owned enterprises, representing 20 per cent of all the enterprises. Most of them are managed and operated by a single person but provide direct employment for an estimated 22-27 million people. Even though the numbers show a sudden spurt in women entrepreneurship, a sizeable number of these enterprises are run by male counterparts and the ownership of women remain only in papers. The virtue of women entrepreneurship has not been accepted in the traditional Indian social setup and ignored its potential as a game-changer in women empowerment in the country. However, the urban population has acknowledged the capability of women and entrusted them with greater responsibilities in the corporate world.

The Government of India has undertaken several programs wherein entrepreneurs are trained on all, technical, managerial and other related skills so that they may enter the industrial field confidently with risk-bearing capacity and manage their units on scientific lines. In this context, it is important to recognize that in entrepreneurship development equal importance has to be given to potential and prospective women entrepreneurs. Given the important role women can play in the industrial scene, the Government of India is encouraging them 
and trying to bring them into the fold of industrial activity. But it seems that women have not responded as favourably as expected. Probably the customs and tradition are generally against their assuming new roles, which are mistakenly regarded as roles of men.

Unemployment in rural areas has been on the increase and migration from rural to urban in search of livelihood has become a greater and vexing problem. An estimate by the Planning Commission placed employment backlog at about 28 million by the beginning of Eight Plans. And their number is sure to have increased perceptibly since then. Among the countless employment seekers, a major portion is from rural areas. Therefore, it is necessary to develop small-scale industrial units in areas where there is chronic unemployment, dearth of capital, lack of appropriate technical know-how, and certain inherent structural imbalances and bottlenecks in the economy. As the small sector has a high potential for employment generation, there is plenty of scope for the dispersal of industrial units over a wide area so that regional imbalances are narrowed down, untapped local resources are utilized and also entrepreneurship among women could be promoted in the process. Towards this, the government of India has tried to provide financial and managerial assistance.

In India, a very substantial portion of women are unemployed though they can undertake varied activities including industrial activity. Therefore, it is essential to expose them to the various employment profit generating avenues and promote and develop entrepreneurship among them. And it is a fact that in some parts of our country, some women have established beyond any doubt, their competence as successful entrepreneurs. But unfortunately, this development has taken place in cities only. And the rural women are still caught in the targeted levels of poverty, restricting social traditions, customs, and prejudices. Hence, it is quite necessary to emancipate them and bring them into the fold of entrepreneurship.

\subsection{Scope of women's entrepreneurship}

Women can venture into any area of business industry and the service sector depending on their interest, inclination, and aptitude depends upon their educational background, family social status, income level, nature of training if they have had any technical knowledge, entrepreneurial background, and so on. Women can venture into these and other activities by getting trained in those fields and the related areas. The government and allied agencies have been providing training facilities through various Entrepreneurship Development Programmers (EDPs). Financial institutions are also directed to purvey financial and managerial assistance to women entrepreneurs. Women can choose to invest in MSMEs, the cooperative sector, or the khadi and village Industries sector.

MSME Sector: The micro and small-scale Sector is a major area in which enthusiastic, talented women can start several small units. The field is vast and as many prospective women, entrepreneurs, as can venture, would find openings in it. It provides avenues in various areas where raw material and labour and other infrastructural facilities are abundantly available. It is easy to start units in this sector as it depends totally on locally available resources. All entrepreneurs who are prepared to invest up to Rs.75 lakhs in fixed assets can start a tiny unit in rural and backward areas. There is fair evidence of women all by 
themselves managing tiny sectors very successfully. It is their commitment, hardworking and risk-bearing natures that make fortunes of their units and enable them to succeed. As women in India are still in the male dominating environment, it needs some effort for them to break themselves free of restriction to prove themselves as successful entrepreneurs. As small units are labour-intensive based on indigenous technology, locally available resources, and their flexibility in changing the product line, it is not difficult for them to succeed in this sector. Once women establish themselves as successful entrepreneurs, they can provide employment opportunities to a considerable number of unemployed educated women. They can start units in the manufacturing sector as well as the service sector in which there are several approaches for prospective women entrepreneurs.

Rural Sector: Rural industries are vital for the development of rural areas, though they are generally associated with agriculture, forest produce and handloom. Rural industries are characterized by the high potential for employment and income generation. These industries are using locally available raw materials and operate with low investments in plants and machinery. Women can successfully venture into various rural industries such as bee-keeping, making of hand-made papers, bags, carpentry, bio-gas, making of palm gur, candles, perfumes, matchbox, soaps and non-edible oils, leather goods, processing of pulses and cereals, fruit-processing and the preservation etc. Increased women participation in such ventures in rural areas leads to their self-sufficiency and greater economic freedom. Microenterprises in rural areas have a commendable role in empowering women in rural areas. They provide gainful employment to women and helps to develop personal and social capabilities in them. Women entrepreneurship in microenterprises gives them much needed financial independence, self-confidence and a better standard of living. Economic betterment of women leads to equal socio-economic opportunities, gender justice, property rights, political representations and ultimately results in the overall development of the nation.

\subsection{Institutional support for women entrepreneurship in India}

To foster women's entrepreneurship in our country, several institutions have launched special programs and schemes with a variety of packages. They are intended to provide financial as well as managerial support to them to set up their units in areas of their interest. The government of India canalizes assistance through these institutions for developing their ventures. In India, there are several credible institutions established for the development of women entrepreneurship, namely, Canara Bank Centre for Entrepreneurship Development for women (CED), Entrepreneurship Development Institute of India (EDII), Andhra Pradesh State Financial Corporation (APSFC) Women Entrepreneurship Scheme, IFCI Interest Subsidy Scheme, IDBI Mahila Vidhya Nidhi Scheme, National Institute for Entrepreneurship and Small Business Development (NIESBUD), Centre for Entrepreneurship Development of Karnataka (CEDOK), SBI Shree Shakthi Scheme etc. 


\section{Discussion and Findings}

This study produced results which corroborate the findings of a great deal of the previous work in women entrepreneurship. The expert interview with the women entrepreneurs was used to collect context information and insights on their problems.

\subsection{Impediments to women entrepreneurship in India}

The problems and constraints experienced by women entrepreneurs have resulted in restricting and inhibiting the expansion of women's entrepreneurship. The major barriers encountered by women entrepreneurs are:

\section{a. Lower confidence in business skills:}

In the male dominating social set-up, family members do not have much faith in women possessing the abilities of decision-making. They often underestimate the capabilities and skills of their women. Similarly, as women are accepting a subordinate status, they too develop a false notion that men are more competent when it comes to financial matters.

\section{b. Lack of working capital:}

When it comes to entrepreneurship, women are considered in the high-risk category by the potential funders. Indian women rarely own property and other valuable assets which can be used as collateral for loans. They often depend on their family for their financial needs. Investors too have apprehensions to support entrepreneurial ventures by women.

\section{c. Socio-cultural barriers:}

Women have to perform multiple roles in the family and it is very difficult for them to create a work-life balance unless they have been given flexible working hours and space. The system of social setup is patriarchal in nature in which men hold predominant roles in financial decision making, political representations and control of the property. In case of financial stress in the family, the girl child has to leave education for her brother. Successful women entrepreneurship requires overcoming all these socio-cultural barriers. As a result, this impedes the progress of women and handicaps them in the world of work. So, while putting a step ahead into the entrepreneurial world or any other profession, women need to think several times because of lack of confidence, economic dependence, and social bindings.

\section{d. Safety in work and public places:}

Since women represent approximately 25 per cent of the total workforce in India, ensuring safety in work and public places is of utmost importance for the physical, intellectual, emotional, the well-being of women. The root cause of violence and oppression against women is the lack of a value system in society. The frequent atrocities against women at workplaces restrict women's mobility and thereby, their economic participation and freedom. 


\section{Conclusion}

Women empowerment through entrepreneurship has assumed greater importance in the economic progress of an emerging economy like India. The development of a sound entrepreneurship culture is an indicator of the empowerment of people, industrial development, and the overall development of a country. The development of an economy mainly depends on entrepreneurial ability, competence, and perseverance of the people in general and women in particular. India has to sort out, nourish and develop competent entrepreneurship, which is very vital for its rapid industrialization and empowerment of the people. Despite the government level efforts for providing a congenial atmosphere for women entrepreneurship and thereby women empowerment in the country, the progress is still far behind expectations. The ongoing Covid pandemic crisis and industrial sickness discourage women to take up entrepreneurship risks. Women entrepreneurs should be given adequate motivation, guidance, training and financial support for taking up challenging entrepreneurial tasks. The fostering of women entrepreneurship leads to their empowerment and contribute to the uninterrupted economic development in challenging times. 


\section{References}

Anand, S., \& Sen, A (1995). Gender Inequality in Human Development: Theories and Measurement. Readings in human development, OUP, New Delhi.

Asian Development Bank (2013). India, gender equality diagnostic of selected sectors, Philippines.

Bain \& Company (2019). Women entrepreneurship in India. Bain \& Co. and Google, New Delhi.

Carter, S. L., \& Shaw, E. (2006). Women's business ownership: Recent research and policy development. Retrieved July 2, 2021, from https://strathprints.strath.ac.uk/8962/1/sbs_2006_report_for_bis. pdf.

D’Souza, O. (2012). Truth about Dalits, caste system, and untouchability. London Institute of South Asia, UK.

Francine, F. (1978). India's Political Economy (1947-1977). The gradual revolution, Princeton university press 1978 MSU CN.

International Labour Organisation (2018). Women and men in the informal economy-A statistical picture, 3rd eds., ILO office, Geneva.

Mayoux, L., (2000). Micro-finance and the empowerment of women: A Review of the key issues, International Labour Organization, Geneva.

Malach-Pines, A., Lerner, M., \& Schwartz, D. (2010). Gender differences in entrepreneurship: Equality, diversity and inclusion in times of global crisis. Equality, Diversity and Inclusion: An International Journal, 29(2), 186-198. https://doi.org/10.1108/02610151011024493

Meuser, M., \& Nagel, U. (2009). The expert interview and changes in knowledge production. In Interviewing experts (pp. 17-42). Palgrave Macmillan, London.

OECD (2020). Women's economic empowerment, Paris, France.

Orhan, M., \& Scott, D. (2001). Why women enter into entrepreneurship: An explanatory model. Women in Management Review, 16(5), 232-244. https://doi.org/10.1108/ 09649420110395719

Sarri, K., \& Trihopoulou, A. (2005). Female entrepreneurs' personal characteristics and motivation: A review of the Greek situation. Women in Management Review, 20(1), 24-37. https:// doi. org/10.1108/09649420510579559

Schreier, M. (2012). Qualitative content analysis in practice. Sage publications.

Singh, J. S. (1998). Creating a new consensus on population: the International Conference on Population and Development. Earthscan.

The Wire (2021). India slips 28 places in WEF's gender gap index, ranked 140th among 156 nations. Available at https://thewire.in/gender/india-slips-28-places-wef-gender-gap-index-ranked-140thamong-156-nations.

United Nations Development Programme (1995). Human Development Report. Available at http://hdr. undp.org/en/content/human-development-report-1995

United nations Development Programme (2000). Human Development in South Asia Report.

United Nations Development Programme (2020), Human Development Report. Available at http://hdr. undp.org/sites/default/files/hdr2020.pdf

United Nations Organization (2012). Employment: What does it mean to you? UN Social Development Network. 
UNFPA (1995). Report of ICPD Programme of Action. UNO, UNFPA.

United Nations Organisation (2020). Sustainable Development Goals. UNO.

United Nations Organisation (2020). The world's women 2020: Trends and statistics. Department of Economic and Social Affairs, Geneva.

United Nations organisation (2021). Gender equality and women's empowerment - United Nations Sustainable Development. UNO.

United Nations Organisation (2020). Sustainable development goals, goal 5-gender equity. Available at https://www.un.org/sustainabledevelopment/gender-equality/.

United Nations Population Fund (2008). Annual Report, 2007. UNO.

UN Report (2020). The world's women 2020: Trends and statistics, UNO: New York.

UN Women $(2018,2020)$. The 1995 Fourth world conference on women, Beijing: UN Women.

UN Women (2020). Facts \& figures: Economic empowerment. Available at https://www.unwomen.org/ en/what-we-do/economic-empowerment/facts-and-figures.

World Economic Forum (2021). Global Gender Gap Report. Available at https://www.weforum.org. 